\title{
Aetiological factors in obesity
}

\section{By E. Goтн, János Hospital, Budapest, Hungary}

It is a rather difficult task to give a review on the aetiology of obesity, as in spite of the intensive investigations of the last two decades, we have to confess that we do not know much about the aetiology.

The problem of obesity is complex. Besides social and economic aspects, biochemical, genetic, neural and psychological factors are closely interacting.

Changes in the energy balance have a role in the genesis of obesity. As a consequence of civilization, physical activity has decreased and food supplies have become abundant. Among Jews living under nomadic conditions in Yemen there was no obesity or diabetes, but $15^{-20}$ years after their immigration to Israel these illnesses became as common as they are in general in the civilized countries. However, among these people obesity is found only in some instances.

It is possible that obese people require more food to perform the same physical activity. According to Lincoln (1972) the energy intake of obese youngsters is lower than that of subjects of normal body-weight. The considerably lower energy intake relative to body-weight can mean that in spite of obesity the nutrient supply of the living tissues is inadequate. Therefore, the concept that obesity is the result of inactivity can be reversed: an obese person deliberately restricts the energy intake and consequently reduces physical activity.

Obesity cannot be simply explained by the energy balance. According to a number of publications it can be established that obese people consume less energy than subjects of normal weight (e.g. Johnson, Burke \& Mayer, 1956; Stefanik, Heald \& Mayer, I959).

Opinions on the subject of energy output are different. According to some authors obese people do less physical work (Johnson, et al. 1956; Dorris \& Stunkard, I957; Stefanik, et al. 1959; Bullen, Reed \& Mayer, I964; Bloom \& Eidex, I 967). On the other hand, other workers have not found decreased physical activity in obese subjects (McCarthy, r 966; Maxfield \& Konishi, I966). Reviewing the literature, Miller \& Mumford $(1966)$ came to the conclusion that in the aetiology of obesity, factors other than increased food intake and decreased physical activity must be studied.

We are not contradicting the law of conservation of energy if we do not identify the concept of food intake with the utilization of food. The processes of food utilization may be pathological in obese subjects.

There are many examples of instances in which persons with the same energy intake are found to show different changes in body-weight. Kekwick \& Pawan (1964) found that if they gave rats a low-energy diet, the rats lost more weight 
when $90 \%$ of their diet was fat than if they were given a diet containing $90 \%$ carbohydrate, as the amount of unused energy excreted with urine increased. The same authors fed one group of rats normally, the other group by a stomach-tube, and found that the body-weight of the latter group was greater (Kekwick \& Pawan, 1966). Feeding frequency also influenced body-weight.

In this paper I will discuss the problems of over-nutrition and decreased energy output, i.e. the neural, psychosomatic pathomechanism of obesity, and will consider the disturbances of metabolic, hormonal and enzymatic regulation. The first factor may be termed regulatory obesity, the second metabolic obesity. However, the question arises whether the two forms of obesity can be definitely separated clinically.

\section{Neural, psychical factors}

Hypothalamus. It is known from animal experiments that there is a centre of sensation of satiety and one of hunger in the hypothalamus. Clinical observations have confirmed the existence of these centres (e.g. obesity observed in the instances of injuries or tumours in the hypothalamus). Food consumption results in greater pleasure or--in stress situations-in greater satisfaction for obese people and the pleasant sensation lasts longer, i.e. satiety arises later. According to Schachter, Goldman \& Gordon (I968) and Schachter \& Gross (I968) obese people eat similar amounts of food both after some hours of food deprivation and after they have been given plenty of food. Similarly, Cabanac \& Duclaux (1970) found that in obesity there is a lack of satiety, and obese people ate sweets and sugar with pleasure after consuming sugar, in contrast to subjects of normal weight.

Psychosomatic relationship. The feeling of satiety and hunger leads to the question of psychosomatic relationship and personality.

Obesity is a human illness; wild animals do not grow fat. In captivity only some animals grow fat, e.g. the lion, while a roe-deer remains slim. This indicates also the importance of genetic aetiology.

In human beings the relationship between the parents and their child will not be determined primarily by biological factors but by social and emotional factors. The emotional experiences of food consumption are connected throughout life with eating. According to Bruch (1943), the development of excess weight is a result of incorrect learning experiences which result in incorrect regulation. Food has a symbolic importance too. Food can represent desire after unattainable love, it can be the source of mightiness or power, it can convey the emotion of hate or anger, protection against becoming adult and responsible. In obese subjects the original physiological function of nutrition moves into the background.

Excess food consumption mainly induces obesity if there is trouble in neural, cormonal or enzymatic regulation, and it lasts even if the energy intake is lower than hat of subjects of normal weight.

Size and number of fat cells. Fat cells of the obese are larger or their number is ncreased (Björntorp, Hood, Martinsson \& Persson, 1966; Hirsch, Knittle \& Jalans, I966). According to Björntorp \& Sjoström (1971) hyperplasia based on the nultiplication of fat cells and hypertrophy based on cell enlargement are found 
together. In children hyperplasia is characteristic (Brook, Lloyd \& Wolff, 1972). The earlier the obesity of adult, fat people begins, the greater the number of fat cells which can be observed. According to these authors those children whose fat tissue is hyperplastic have an abnormal store of fat by the end of their first year of life. Beyond this age the fat cells multiply proportionally only with the growth of the child.

Björntorp \& Sjoström (1971) distinguished between two kinds of obesity: in the first type, disturbances in carbohydrate and fat metabolism, arteriosclerosis and diabetes are prevalent, in the second one, the metabolism is relatively normal. They therefore assumed that obesity could be benign and malignant. In hyperplastic obesity genetic and nutritional factors were also involved, with much less metabolic disturbance; this was the benign form.

\section{Metabolic, hormonal and enzymatic changes}

Carbohydrate metabolism. Obesity and diabetes are often found together. From the aspect of pathogenesis of obesity prediabetes should be mentioned. If both parents are diabetic, or if the mother shows the following symptoms: excessive fat deposition during pregnancy, large babies, abortions, stillbirths, hypertrophy of the beta cells in the foetus, diabetes is often found. According to Cerasi \& Luft (I972) the glucose tolerance is still normal in prediabetes but the insulin-response to glucose is decreased. As prediabetic mothers are obese, it is possible that the reduced sensitivity of beta cells is involved in the aetiology of obesity. However, it is known that the insulin secretion of obese subjects is increased, which seems to be contradictory. In experimental human obesity, increased insulin secretion is apparently a consequence of the obesity.

Fat metabolism. In obesity free fatty acid, triglyceride and cholesterol concentrations in the serum are often increased. Their role in the aetiology of obesity is not yet known.

Endocrine disturbances. Some obese subjects suffer from endocrine illnesses. Diagnoses made in 300 obese patients were as follows: Lawrence-Moon-Biedl $\mathrm{I}$, Stein-Leventhal 2, Cushing 8, Myxoedema r9, kryptorchism 20, prediabetes 23, idiopathic oedema 29, hyperostosis frontalis 52 and 'obesity' 146 . In Cushing's syndrome the cause of obesity can be the increased insulin secretion stimulated by cortisol hypersecretion. According to Sétáló (I965), increased cortisol secretion does not cause obesity because mild alloxan-diabetic rats do not grow fat when treated with cortisol, while control animals do. Obesity is not characteristic of myxoedema but they can occur together. We have often observed fat boys with kryptorchism or with hypogonadism which can be considered as functional Frölich syndrome. Idiopathic oedema is common among obese people; on average one in every ten obese subjects exhibits oedema of non-cardiac origin. The existence of the Morgagni syndrome is doubtful, but among obese subjects hyperostosis frontalis interna is more common.

Of the hormones which may be implicated in obesity I have already mentioned insulin. There are others which may be of importance. 
Growth hormone (STH). The secretion of STH in response to arginine- and insulininduced hypoglycaemia is decreased in many obese subjects. (Ball, El Khodári \& Canary, I972; Girard, Stahl, Nars \& Baumann, I972; Goth \& Gönczi, I972). STH secretion in the hypothalamus-injured obese rat is also decreased (Bernardis \& Frohman, 1970).

Cortisol. Cortisol secretion is decreased by insulin hypoglycaemia (Goth \& Gönczi, I972). According to many authors adrenocortical activity is increased in obesity. However, Migeon, Green \& Eckert (I963) did not find any correlation between adrenalcortical activity and the degree of obesity, and Mattingly \& Tyler (1967) did not find increased cortisol excretion in instances of obesity. Obesity develops in Cushing syndrome and after long treatment with steroids, probably as a result of insulin hypersecretion caused by cortisol stimulation.

Hormones of the thyroid gland. The effect of the antithyroid drug Metimazol is to decrease in vitro fat-mobilizing activity of human plasma, while administration of thyroid extract increases this activity (Goth, unpublished results).

To summarize the endocrine changes in obesity, secretion of the antilipolytic and lipogenesis-stimulating hormone, insulin, is increased, while secretion of the lipolytic hormone, STH, is decreased. The role of cortisol is not clear. Thyroid hormones also appear to be involved in the regulation of lipolysis. These hormonal changes may have a role in the aetiology of obesity, but it is possible that in many instances the hormonal changes are only consequences of obesity, although they may enhance the progression of fat deposition.

Lipotropins. Burns, Hales \& Stockell-Hartree (1967), Trygstad (1968), Storring, Burns, Furnival, Hales, Langley \& Stockell-Hartree (I97 I) extracted lipotropins from the human pituitary gland. We isolated pure lipotropic polypeptide from the human pituitary. The amino acid composition of this substance is similar to that of porcine $\beta$-lipotropin and its molecular weight is about ro 000 . It markedly increases lipolysis in rabbit fat tissue, but its effect on lipolysis in rat adipose tissue is slight. At the level $0 . \mathrm{r} \mu \mathrm{g} / \mathrm{ml}$ it increases lipolysis in human adipose tissue (Cseh, Gráf \& Goth, 1968). The isolated compound is distinguishable from the known human hormones of the pituitary.

Chalmers, Pawan \& Kekwick (I960) extracted a fat-mobilizing substance (FMS) from urine. We have found that the best method for the detection of this factor is that described by Pawan (197I), which is based on the increase of the ketone-body concentration in the blood of mice.

Whether or not the reduced secretion of lipotropins is important in the development of obesity is open to question. According to Pawan (1971) the FMS excretion of obese people is reduced.

Blood plasma from obese subjects has a slight effect on the fat-mobilizing activity of adipose tissue of rats but paradoxically it is raised by glucose loading. The fatmobilizing activity of plasma from a subject of normal weight is higher, and after glucose loading decreases within $2 \mathrm{~h}$ (Goth \& Fövényi, I969). Adipose tissue of obese persons exhibits a smaller lipolytic response to epinephrine than that of normal subjects (Fövényi, Goth, Koncz \& Zétény, I968). Recently the same observation 
was made by Gries, Berger, Neumann, Preiss, Liebermeister, Hesse-Wortmann \& Jahnke (1972).

Only a few studies have been done on the enzymatic changes in adipose tissue of obese people. It is still doubtful whether the enzymatic changes have an aetiological role or whether they are only consequences of fat-cell enlargement.

\section{Summary}

The aetiology of obesity is complex. Social, economic, biochemical, genetic, neurological, psychological and personality factors are involved. Obesity cannot be explained only by changes of energy balance. Metabolic, hormonal and enzymic changes can be demonstrated. It is possible that these are not the primary aetiological factors but that they are consequences of obesity.

\section{REFERENCES}

Ball, M. F., E1 Khodari, A. Z. \& Canary, J. J. (1972). J. clin. Endocr. Metab. 32, 498.

Bernardis, L. L. \& Frohman, L. A. (1970). Neuroendocrinology 6, 3 I 9.

Björntorp, P., Hood, B., Martinsson, A. \& Persson, B. (1966). Acta med. scand. х80, i 7.

Björntorp, P. \& Sjoström, L. (1971). Metabolism 20, 703 .

Bloom, W. L. \& Eidex, M. F. (1967). Metabolism 16, 679.

Brook, C. G. D., Lloyd, J. K. \& Wolf, O. H. (1972). Br. med. F. 2, 25.

Bruch, H. (1943). Am. F. Psychiat. 99, 752.

Bullen, B. A., Reed, R. B. \& Mayer, J. (1964). Am. F. clin. Nutr. 14, 2 I I.

Burns, T. W., Hales, C. N. \& Stockell-Hartree, A. (1967). F. Endocr. 39, 2 г3.

Cabanac, M. \& Duclaux, R. (1970). Science, N.Y. 168, 496.

Cerasi, E. \& Luft, R. (1972). Diabetes 21, Suppl. 2, 685.

Chalmers, T. M., Pawan, G. L. S. \& Kekwick, A. (1960). Lancet ii, 6.

Cseh, G., Gráf, L. \& Goth, E. (1968). FEBS Letters 2, 42.

Dorris, R. J. \& Stunkard, A. J. (1957). Am. 7. med. Sci. 233, 622.

Fövényi, J., Goth, E., Koncz, F. \& Zétényi, D. (1968). Magy. belorv. Archum. 21, 238.

Girard, J., Stabl, M., Nars, P. W. \& Baumann, J. B. (1972). Klin. Wschr. 50, 706.

Goth, E. \& Fövényi, J. (1969). Acta med. hung. 26, 255.

Goth, M. \& Gönczi, J. (1972). Endokrinologie 60, 8.

Gries, F. A., Berger, M., Neumann, M., Preiss, H., Liebermeister, H., Hesse-Wortmann, C. \& Jahnke, K. (1972). Diabetologia 8, 75 .

Hirsch, J., Knittle, J. L. \& Salans, L. B. (I966). F. clin. Invest. 45, 1023.

Johnson, M. L., Burke, B. S. \& Mayer, J. (1956). Am. F. clin. Nutr. 4, 37.

Kekwick, A. \& Pawan, G. L. S. (1964). Metabolism 13,87.

Kekwick, A. \& Pawan, G. L. S. (1966). Metabolism 15, 173.

Lincoln, J. E. (1972). Am. \%. clin. Nutr. 25, 390.

McCarthy, M. C. (1966). F. Am. diet. Ass. 48, 33.

Mattingly, D. \& Tyler, C. (1967). Br. med. F. 2, 394.

Maxfield, E. \& Konishi, F. (1966). F. Am. diet. Ass. 49, 406.

Migeon, C. J., Green, C. D. \& Eckert, J. F. (I963). Metabolism 12, 718.

Miller, D. S. \& Mumford, P. (1966). Proc. Nutr. Soc. 25, 100.

Pawan, G. L. S. (1971). In Polypeptide Hormones p. 177 [E. Goth and J. Fövényi, editors]. Budapest: Akad. Kiadó.

Schachter, S., Goldman, R. \& Gordon, A. (1968). J. Personality soc. Psychol. xo, 91.

Schachter, S. \& Gross, L. P. (1968). F. Personality Soc. Psychol. ro, 98.

Sétáló, G. (1965). Acta physiol. hung. 27, 375.

Stefanik, P. A., Heald, F. P. \& Mayer, J. (1959). Am. 7. clin. Nutr. 7, 55.

Storring, P. I., Burns, T. W., Furnival, B. E., Hales, C. N., Langley, P. \& Stockell-Hartree, A. (I97I). In Polypeptide Hormones p. 205 [E. Goth and J. Fövényi, editors]. Budapest: Akad. Kiadó.

Trygstad, O. (1968). Acta Endocr, Copenh. 57, 8 I. 